\title{
Transatlantica
}

Revue d'études américaines. American Studies Journal

2 | 2014

Aesthetics of Theory in the Modern Era and Beyond / Photographie documentaire

\section{Mark Duffett, ed., Popular Music Fandom. Identities, Roles and Practices}

London, Routledge, 2014

\section{Claude Chastagner}

\section{CpenEdition \\ Journals}

\section{Electronic version}

URL: https://journals.openedition.org/transatlantica/7203

DOI: 10.4000/transatlantica.7203

ISSN: $1765-2766$

Publisher

Association française d'Etudes Américaines (AFEA)

\section{Electronic reference}

Claude Chastagner, "Mark Duffett, ed., Popular Music Fandom. Identities, Roles and Practices",

Transatlantica [Online], 2 | 2014, Online since 20 December 2019, connection on 01 February 2023

URL: http://journals.openedition.org/transatlantica/7203; DOI: https://doi.org/10.4000/transatlantica. 7203

This text was automatically generated on 1 February 2023

\section{(c) $($ ) $\odot \odot$}

Creative Commons - Attribution-NonCommercial-NoDerivatives 4.0 International - CC BY-NC-ND 4.0

https://creativecommons.org/licenses/by-nc-nd/4.0/ 


\title{
Mark Duffett, ed., Popular Music Fandom. Identities, Roles and Practices
}

London, Routledge, 2014

\author{
Claude Chastagner
}

\section{REFERENCES}

DUFFETT, Mark, ed., Popular Music Fandom. Identities, Roles and Practices, London: Routledge, 2014, 233 pages, ISBN 13: 978-0-415-50639-7, 76.09 livres.

1 “The broader depictions of fans beginning in the early 1990's as not only consumers, but producers [...], and not only individual fanatics, but members of communities with shared norms, values, and interpretations of texts [...], marked a turning point in research on fans" (186). "By participating in fandom, fans [...] enter a domain of cultural activity of their own making which is, potentially, a source of empowerment in struggles against oppressive ideologies and the unsatisfactory circumstances of everyday life (in Lewis 1992, 3)" (167).

2 These two excerpts from the collection of essays edited by Mark Duffett, a senior lecturer at the University of Chester, set the tone: fandom, the "regular, emotionally involved consumption of a given popular narrative or text" (128), is a respectable topic, worthy of the attention of academics, a fact this collection, the product of a one-day symposium at the University of Chester in 2010, confirms. In his excellent introduction, Duffett draws a historiographical panorama of research on fandom, of which he is himself a leading expert. The early critics dealing with fans (who are, after all, key to the success of popular music), were mostly negative. They connected fandom with mass culture, which, as seen by the American Left or the Frankfurt School, was the mere product of the entertainment industry. Accordingly, fans were labeled as "passive consumers", "infantilized", or "alienated" (1). One set of explanations focused on their psychological shortcomings, while the second stressed their social inadequacies. At any rate, they were considered "vulnerable and unfortunate human subjects" (2). A second 
phase developed in the late 1960s when popular music, now labeled "rock", started to be analyzed as an artistic and politicized form. Consequently, critics tended to separate the various "mania" of the era (hysterical and feminized) from the more serious, and politically mature behaviors, worthy of interest. From the 1970s onward, in the wake of the contestation of cultural elitism, a new vision of the consumer emerged, endowed with power and sovereignty, which deprived critics of their clout and authority, and relegated them to the role of "consumer guides" (3). Released from the critics' stern condescension, a new generation of young academics prized fans as "autonomous free individuals" (3), a move the explosion of the Internet strengthened.

3 For Duffett, the Internet has partially transformed fandom. If the fascination with music, the emphasis on the star system, and the tendency to constitute closely knit communities remain, it has now become impossible to ignore the fans' capacity to comment, analyze, transform, and re-invent the music of their idols with a stupendous degree of intelligence and imagination, to the point that fans' communities have now become a central element of record companies' marketing strategies. Today, thanks to the Internet, these communities are more powerful and visible, though with the development of online piracy, they are also often stigmatized as responsible for what seems to be the programmed, inevitable collapse of the culture industries.

4 Two books were particularly instrumental in the new perception of fans and fandom, Henry Jenkin's Textual Poachers (1992), focusing on how fans operate, and Lisa Lewis's The Adoring Audience (1992), devoted more specifically to music. However, research on the subject has up to now remained sketchy and sporadic, focusing mainly on purely musicological, or sociological aspects. Seldom have the actual practices of fans been taken into account, which is precisely the point of this collection: a demonstration that music fandom is a rich, complex phenomenon, impossible to reduce to a few stereotypical features, and that on the contrary it must be analyzed as "a range of tastes, roles, identities, and practices" (7). The collection, made up of papers given at the symposium, along with original essays specifically written for the occasion, and revised versions of earlier articles, covers the various aspects of fans' practices duly and thoroughly taken into account.

In the first article, "Back in the Mix", Matt Hills explores the subject of fandom devoted to record producers (here, Trevor Horn and Tom Lord-Alge), an unusual, and often marginalized, object of focus, both for fans and researchers. The outcome of this type of fandom activities is to "make visible a range of production personnel and collaborators" (18), who contrary to "popular" wisdom, do not get in the way of more traditional fanartist relations, but rather "extend the artist-centered fan experience outside its archetypal domain" (32). In "Beyond Capital, Towards Myth", Beate Peter focuses on electronic dance music's enthusiasts, and their clubbing activities, from a political perspective. She shows that "the internal logic and structure of fan communities can elude formations based on capital and class", suggesting that electronic dance music fan cultures can be seen as "postliberal aggregates" (37), which, though often eluding specifically resistant stances, contrary to punk for instance, can nevertheless "escape the control of sovereign powers" (51) by means of what Peter calls "imperceptible politics" (41). Nedim Hassan's chapter deals with the impact of music on fans with learning and verbal articulation difficulties, bearing on Grossman's notion of affect. He recalls the importance of taking into account notions such as access and restriction, inclusion and exclusion as regards fans' behavior, and the extent to which everyday 
activities can be revealing about processes of self-identity, with texts becoming both personal and social resources.

6 In his alert, and introspective essay, Alexei Michailowsky takes his own case for object of study: "what are the implications of carrying out research on one's favorite artist [here, Brazilian Marcos Valle]? How does the fan inside deal with the researcher, and vice-versa? Would a researcher come to the same conclusion if he or she was not a fan?" (71) Written in the first person, his essay concludes on the ambivalent statement that research can be both spurred on and hampered by a strong, personal, commitment. Mark Duffett has been able to secure a rare treat, a revised and annotated article by Fred Vermorel, initially published in the Village Voice Literary Supplement. Vermorel provocatively suggests that biographers, the private detectives of popular music, are the equivalent of stalkers intruding for commercial reasons upon the artists' private lives, and in the process acting by proxy for the fans.

7 Including John Coltrane in a book on fandom could come as a surprise, for one would not readily associate fandom with jazz, but the essay by Tony Whyton is further proof the phenomenon goes indeed beyond the passing infatuations of teenagers, and that academic research must acknowledge its scope. The paper focuses on jazz musicians as fans, through the triple lens of religiosity, pathology, and cultural value. If the author criticizes the first approach, in that it casts fans as "passive, servile and misguided" (98), it is nevertheless in spiritual terms that many musician fans describe their relation to Coltrane, while stressing that emulating their master is not "deviant or obsessive behavior" (106). Even more revealing, Whyton shows how musicians use their fan relation to Coltrane to establish their own cultural credentials and distinguish themselves from musicians unable to follow such a demanding artist, who rejected both popular culture and the star system: "musicians inspired by Coltrane use his legacy to police the boundaries of their own musical practice and to legitimate their own careers" (112).

Can one be fan of a place? This is the question Cornel Sandvoss addresses in his farreaching essay, based on first-hand experience and the numerous testimonies of British clubbers from Ibiza. Sandvoss considers the question legitimate in so far as places are texts, "socially constructed through symbols, discourses and representations" (115), without clearly defined boundaries. He eventually delineates two categories for the legitimization of fandom for Ibiza: first, the sense of belonging and attachment; second, the network of communitas (or "neo-tribes" according to French sociologist Michel Maffesoli's terminology), both leading fans to experiencing the island as a place of peace and harmony. Sandvoss concludes that "conceptualizing the interplay between place and music through fandom avoids the misleading discourses of autonomy and authenticity that underscore dominant theorizations of music, emotion, and identity" (139). Mark Duffett's own paper constitutes a reflective pause in the series of case studies, pondering as he does on the different meanings taken by the word "love" when used by fans to describe their attachment to an artist. The various layers of sense he excavates, far from excluding one another, rather make the notion more complex and richer through a palimpsest of interrelated notions.

9 Roy Shuker wonders what distinguishes collectors from fans. Is it age, economic power, degrees of commitment, cultural capital? His essay evokes various analyses of the act of collecting, notably Jean Baudrillard, before focusing on collecting Beatles records and memorabilia. The penultimate contribution deals with Deadheads, the fans of The 
Grateful Dead, and especially of Jerry Garcia, the guitarist, leader and founder of the band, fifteen years after his death. What are the bases of the fans' continuous attachment, of the commitment of the more recent ones who have never seen the band play? Peter Marris' theory of loss and change proves particularly illuminating in this context. Eventually, Joli Jensen, one of the contributors of Lisa Lewis's earlier The Adoring Audience (1992), has the final word. In a brief, but dense paper, she reflects upon the twenty years of research that have elapsed since her first article, and recalling the term "aca-fan" coined by Jenkins, wonders to what extent fans and scholars are really two different entities. Studying fandom can be deemed un-academic a topic only to the extent that it deals with emotional response. But scholars do something fans tend to avoid, something which in a way redeems the apparent lowliness of the subject: they theorize their emotions.

The overall strength of this collection is that by focusing on specific cases of fandom rather than on conceptual frameworks and general theories, the scholars gathered by Mark Duffett from different disciplines manage to avoid the pitfall of establishing a strict canon, a restrictive methodology, a "unifying paradigm to be re-conceptualized" (213). On the contrary, they open up for the fan and the academic alike, a world of possibilities, of methods, subjects, and objects. It is a risky challenge, one that refuses the safety of walking exclusively on the well-trodden paths of, say, issues of identity or resistance. Rather, the authors have chosen to explore the more unsettling and complex question of practice, a choice that gives the book its originality and relevance.

11 For its boldness and appropriateness, this collection of essays deserves a wide readership, extending beyond the realm of popular music academia, but this readership may be unfortunately discouraged by the price of the book and its austere, unattractive cover.

\section{BIBLIOGRAPHY}

JENKINS, Henry, Textual Poachers: Television Fans and Participatory Culture, New York, Routledge, 1992.

---, Fans, Bloggers, and Gamers: Exploring Participatory Culture, New York, New York University Press, 2006.

LEWIS, Lisa A., ed., The Adoring Audience: Fan Culture and Popular Media, New York, Routledge, 1992.

MAFFESOLI, Michel, Le Temps des tribus : le déclin de l'individualisme dans les sociétés de masse, Paris, Méridiens / Klincksieck, 1988.

INDEX

Subjects: Recensions 


\section{AUTHORS}

\section{CLAUDE CHASTAGNER}

Université Paul Valéry Montpellier 